\title{
Expletives in a Null Subject Language and Criteria for Expletiveness: Evidence from Russian ${ }^{1}$
}

\begin{abstract}
The paper presents an analysis of three pronouns used to refer to a right-peripheral complement clause in Russian. It is demonstrated that two of them exhibit properties associated with expletives, which is unexpected at first sight, Russian being a (partial) null subject language. However, these pronouns are shown to have a discourse-related function rather than a syntactic one. The third pronoun under discussion, though used in the same grammatical context, turns out to be referential. The paper offers an account for this fact and proposes that the parameters that have proved to be relevant for differentiating expletives and non-expletives in Russian should be regarded as general criteria for expletiveness.
\end{abstract}

\section{Keywords}

expletive, null subject, Russian, complement clause, referential pronoun

\section{Introduction}

In a number of European languages, the pronoun that refers to a right-peripheral complement clause is assumed to be an expletive (cf. the English "extraposition it", the German es, the French il etc.). This view is commonly associated with the fact that these languages hardly allow subjectless sentences (Roberts and Holmberg 2010 among others). In Russian, at least three pronouns can be

\footnotetext{
${ }^{1}$ This research has been supported by the Russian Foundation for Humanitarian Research (grant no. 17-04-00517(a)). I am thankful to the anonymous SPL reviewers, who have provided numerous helpful comments and corrections. All errors are mine.
} 
used in such construction. These are the pronouns èto ('it, this'), ono ('it') and tak ('so'), exemplified in ( $1 \mathrm{a}-\mathrm{c})$ from the Russian National Corpus (RNC). ${ }^{2}$

(1) a. Èto horošo, čto ty takoj umnyj $i$ rassuditel'nyj. it good-PRED that you so smart and sober.minded 'It is good that you are so smart and sober-minded.'

b. Ono horošo, čto tak proizošlo.

it good-PRED that so happen-PST.SG.N

'It's good that it happened.'

c. Tak slučilos', čto papa umer nakanune. so happen-PST.SG.N that dad die-PST.SG.M day.before '[It] so happened that [my] dad died the day before.'

In the typology proposed in Roberts and Holmberg (2010: 10), Russian is a partial null subject language. This means that null subjects are admissible in Russian, although the conditions under which they are used are more restricted than those in consistent null subject languages. It appears, nevertheless, that two of the three pronouns used to refer to a complement clause in Russian, èto and ono, display a number of properties characteristic of an expletive in (at least) English and German. By contrast, the third pronoun, tak, though apparently similar, turns out to have referential uses only.

The objective of the present paper is to propose an answer to the questions that the existence of three different pronouns in structures with a right-peripheral complement clause in a language raises:

- Why cannot tak be an expletive, while èto and ono can? More generally, what are the factors that may influence the expletive vs. referential status of a pronoun referring to the right-peripheral embedded clause?

- What is the function of èto and ono? Presumably, it is not the function of filling the subject position, normally associated with expletives, Russian being a (partial) null subject language.

- Can the properties by which èto and ono differ from tak be generalized as criteria for expletiveness?

Although this research is based mainly on the results of the work done on expletives within the generative grammar, as my own framework is basically the functionalism, I will focus here on the semantic nature of expletiveness first of all, namely the assumption that expletives are semantically vacuous or at least semantically impoverished and bear no semantic role (Svenonius 2002; Biberauer and van der Wal 2012, a.o.). As for the structural issues, in

\footnotetext{
${ }^{2}$ The abbreviations used here are: $1=$ first person; $3=$ third person; ACC $=$ accusative; $\mathrm{CNV}=$ converb; DAT = dative; FUT = future; GEN = genitive; INF = infinitive; INST = instrumental; $\mathrm{N}=$ neuter; $\mathrm{NOM}$ = nominative; $\mathrm{PL}$ = plural; $\mathrm{PRED}$ = predicative; $\mathrm{PRS}$ = present; $\mathrm{PST}=$ past; $\mathrm{PTCL}=$ particle; $\mathrm{SG}=$ singular.
} 
particular, the question of what the structural relation is between the pronoun and the right-peripheral embedded clause, they remain beyond the scope of the present study.

The rest of the paper is organized as follows. I present the empirical data on èto, ono and tak in section 2. I propose an answer to the question as to why tak is not an expletive in section 3. In section 4, I discuss the function èto and ono have when they are used as expletives. I summarize the criteria for expletiveness in section 5 . Section 6 concludes.

\section{The empirical data}

I start with the parameters according to which èto and ono can be qualified as expletives in section $2.1 .^{3}$ I go on to analyze tak with respect to the same parameters in section 2.2 .

\section{1. Èto and ono}

Genetically, the pronoun èto is the SG.N.NOM/ACC. form of the demonstrative pronoun ètot ('this'). Ono derives from the nominative form of the 3SG.N personal pronoun ('it'). While èto is a rather neutral item stylistically and grammatically, ono is stylistically and distributionally marked.

Firstly, in the contemporary Russian ono sounds rather archaic. Secondly, ono, contrary to èto, is not inflected for case. Though formally ono appears to be in nominative, this is a fixed form rather than the nominative proper, since ono cannot be used in other case forms. Thus, in (2a) èto stands in the direct object position and it is marked for accusative. Ono cannot be used here, either as ono or as ego, which would be the accusative form of the personal pronoun ono (2b):

(2) a. Ėto vse znajut, čto naš papa

it-ACC all know-PRS.3.PL that our daddy

$v$ komandirovke. (RNC)

in business.trip

'Everybody knows (lit.: it) that our father is on a business trip.'

b. ${ }^{*}$ Ono ${ }^{*}$ Ego vse znajut, čto naš papa $v$ komandirovke.

Note that though the form èto is syncretic between nominative and accusative, in (2) it is the direct object of the transitive verb znat' ('know'), hence, it can be claimed to be accusative. There is, however, a class of predicates that give

\footnotetext{
${ }^{3}$ With respect to èto, some of these parameters have been discussed in detail in Pekelis (2018).
} 
less evidence for differentiation between the nominative and the accusative èto. These are the so-called predicatives, non-agreeing predicates that do not take full noun phrase arguments marked for nominative or accusative, thus providing no distributional "pattern" for distinguishing between two forms of èto (see more on predicatives in section 2.1.4). ${ }^{4}$

Thirdly, ono is used with a small set of matrix predicates. Importantly, these predicates combine with èto as well, i.e. the set of predicates combinable with ono is a proper subset of the set of predicates combinable with èto. A rough list of such predicates complied based on RNC includes the following: horošo 'good', pravda 'true', jasno 'clear', vidno 'clear', ladno 'okay', izvestno 'known', ponjatno 'obvious', verno 'true', stranno 'strange', dosadno 'disappointing', točno 'sure', nado 'needed', nelovko 'uncomfortable', prijatno 'pleasant', legče 'easier', spokojnee 'easier', sdelat'sja 'occur', vyhodit' 'turn out', byt 'be', polučat'sja 'turn out'. In sections 2.1.1-2.1.5, I sketch the distributional traits that èto and ono have in common, which are associated with expletives in at least some European languages.

\subsubsection{New vs. given postcedent}

Both èto and ono can cataphorically relate to new information. This is evidenced in (3a) and (3b) by the fact that the falling accent IK-1 (in the terminology of Bryzgunova (1980)), associated with focus, can be realized inside the complement clause. ${ }^{5}$ A proposition that is given, i.e. mentioned in the previous discourse, would be expected to bear what is usually called tail intonation.

(3) a. Ėto horošo, čto ty takoj umnyj $i$ rassuditel'nyj\. (RNC) it good-PRED that you so smart and sober.minded 'It is good that you are so smart and sober-minded.'

b. Ono, konečno, neploho, čto žizni prizyvnika budet it of.course not.bad that life-DAT conscript-GEN be-FUT.3.SG grozit' tol'ko kulak pjanogo “deda"।, a ne pulja. (RNC) threaten-INF only fist-NOM drunk-GEN bully-GEN and not bullet-NOM 'It is of course not bad that the life of a conscript will be threatened only by the fist of a drunk bully and not by a bullet.'

Importantly, it has been argued in the literature that both the referential English it (see e.g. Birner and Ward 2004) and the German es (Schwabe et al. 2016, a.o.), linked to a right-peripheral complement clause, differ from the corresponding expletives exactly in that only the latter can relate cataphorically to new information.

\footnotetext{
${ }^{4}$ In examples below, èto is glossed for case only if it co-occurs with a conjugated verb.

${ }^{5}$ Here and below, the characters ' $I$ ' and ' $/$ ' are used to denote the focus and the topic accentbearer, respectively.
} 


\subsubsection{Linear order of the pronoun and the clause}

As the examples in (4) and (5) from (Vikner 1995: 239) show, both it and es can only refer to a postposed embedded clause. A preposed embedded clause can only be referred to by a demonstrative referential pronoun (that in English, das in German).

(4) That you came, that /*it annoys me.

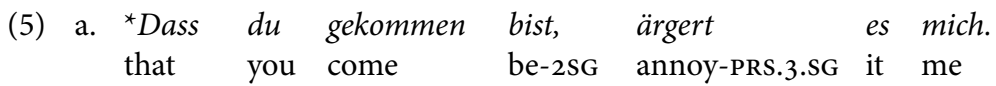
Intended meaning: 'That you came, that annoys me.'

b. ${ }^{\mathrm{OK}}$ Dass $d u$ gekommen bist, das ärgert mich. that you come be-2sG that annoy-PRs.3.sG me 'That you came, that annoys me.'

This link between expletiveness and the linear position is maintained by èto and ono, too. Ono can only precede the embedded clause: while (6a) is perfectly acceptable, (6b) is ill-formed.

(6) a. Ono horošo, čto tak proizošlo. (RNC) it good-PRED that so happen-PST.SG.N 'It's good that it happened.' (RNC)

b. "Čto tak proizošlo, ono horošo. that so happen-PST.SG.N it good-PRED Intended meaning: 'That it happened, that is good.'

Eto, as the examples in (7) shows, is positionally free:

(7) a. Ėto horošo, čto tak proizošlo. it good-PRED that so happen-PST.SG.N 'It's good that it happened.'

b. Čto tak proizošlo, èto horošo. that so happen-PST.SG.N it good-PRED 'That it happened, that is good.'

However, èto displays a number of traits associated with expletiveness only when it precedes the embedded clause. Two such traits are discussed in sections 2.1.3 and 2.1.4.

\subsubsection{Nominative vs. oblique case}

Cross-linguistically, expletives tend to be subjects (Biberauer and van der Wal 2012). The following observation concerning èto seems to be in line with this fact: in case èto precedes the embedded clause, it is more likely to be marked for nominative than for an oblique case. Accordingly, example (8a), in which èto is marked for genitive, is infelicitous, while (8c), with a nominative èto, is 
well-formed. Note also that (8b), in which a genitive èto follows the embedded clause, is perfectly acceptable.

(8) a. ??a ètogo ne znal I-NOM it-GEN not know-PST.SG.M that you so umnyj $i$ rassuditel'nyj. smart and sober.minded

'I did not know (lit.: this) that you are so smart and sober-minded.'

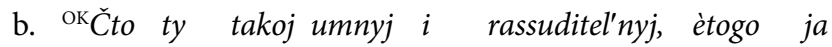
that you so smart and sober.minded it-GEN I-NOM ne znal.

not know-PST.SG.M

'That you are so smart and sober-minded, I did not know that.'
it-NOM make.happy-PRS.3.SG that you so smart
$i$ rassuditel'nyj.
c. Ėto raduet, čto ty takoj umnyj
and sober.minded
'It makes [me] happy that you are so smart and sober-minded.'

However, èto marked for an oblique case can precede the embedded clause if it is clear from the context that the embedded proposition is given. This is the case in example (9): the piece of information 'they were happy' figures in the pre-text.

(9) $\mathrm{Nu}$, estestvenno! Obradovalis'.

well of.course be.happy-PST.PL

- Net, ètogo ne pišet, čto obradovalis'. (RNC)

no it-GEN not write-PRS.3.SG that be.happy-PST.PL

'Well, of course! [They] were happy. - No, [the author] did not write (lit.: it) that [they] were happy'.

According to my assumption, the referential èto differs from the expletive one in that the former can only refer to a prementioned state of affairs. Hence, the data suggest that èto marked for an oblique case can only be referential. This, by turn, fits the tendency for expletives to be subjects.

\subsubsection{Matrix predicate: impersonal vs. personal}

When the nominative èto precedes the embedded clause, it combines almost exclusively with impersonal matrix predicates or predicates that can be used impersonally. By the latter, I mean predicates that at least in some of their uses lack a slot for a canonical subject, namely for a full noun phrase marked with nominative case (see a similar definition of impersonality with a special focus on Russian in Letučij 2011). Most typically, èto preceding the embedded clause co-occurs with a predicative, i.e. a non-agreeing nominal predicate. 
Predicatives are impersonal according to the above definition since they never combine with a full nominative noun phrase (though they do combine with nominative pronouns like èto). By contrast, when èto follows the embedded clause, it co-occurs more often with personal verbs (that is, verbs that cannot be used without a nominal nominative subject). This correlation is based on the analysis of a sample retrieved from the RNC; the statistics can be found in Pekelis (2018). For illustration, see the contrasting examples in (10), which show that the personal matrix verb zaključat' 'contain' is quite felicitous when it follows the embedded clause, as in (10a), but is infelicitous when it precedes the clause, as in (10b). That zaključat' is personal in the intended sense is manifested by the fact that the clause embedded under zaključat' cannot be the only filler of the subject position, so that both (10a) and (10b) are ungrammatical in case èto is omitted. This contrasts with the optionality of èto when it co-occurs with a predicative, as in (11) below.

(10) a. Čto oni byli sčastlivy svoeju ljubov'ju, that they be-PST.3.PL happy their love èto zaključalo $v$ sebe neprijatnyj namjok. (RNC) it-NOM contain-PST.SG.N in oneself unpleasant allusion

'That they were happy with their love, this contained an unpleasant allusion.'

b. 'Èto zaključalo $\quad v$ sebe neprijatnyj it-NOM contain-PST.SG.N in oneself unpleasant namjok, čto oni byli sčastlivy svoej ljubov'ju. allusion that they be-PST.PL happy their love Intended meaning: 'It contained an unpleasant allusion that they were happy with their love.'

As suggested in section 2.1.2, the position of èto before the embedded clause is associated with expletiveness. Given that in many languages constructions considered to be impersonal make use of expletives or non-fully referential subjects (Malchukov and Siewerska 2011: 2), the contrast in (10) can be explained as follows. In (10a), èto is referential, hence it does not need an impersonal predicate to combine with. In (10b), however, there is a contradiction between the position of èto, which suggests its expletive status, and the personal status of the verb, which suggests èto is referential. ${ }^{6}$

Ono, as mentioned in section 2.1.2, can only precede embedded clauses. Importantly, according to the data in RNC, the matrix predicates compatible with ono are only predicates that can be used impersonally, the absolute

\footnotetext{
${ }^{6}$ In fact, personal verbs are compatible with èto that precedes an embedded clause in case the embedded proposition is given. This can be accounted for by the assumption that èto referring to a given proposition (but not the one related to a new proposition) can be assumed to be referential (cf. section 2.1.1). Note that the givenness of the embedded proposition is also a condition that licenses a non-nominative èto in the position before the clause (section 2.1.3).
} 
majority of them being predicatives (see the list of the predicates in section 2.1). So, both èto that precedes the embedded clause and ono tend to combine with impersonal predicates, which is a further trait associated with expletiveness. $^{7}$

It is worth noting, however, that in full accordance with the fact that Russian allows subjectless sentences, neither èto nor ono are obligatory in the impersonal constructions, cf. (11a,b). In this respect, they differ from the English expletive it, cf. (11c). Note that èto is expletive in (11b) according to the three parameters discussed above: it precedes the embedded clause, it is not marked for an oblique case, and it co-occurs with a predicative.

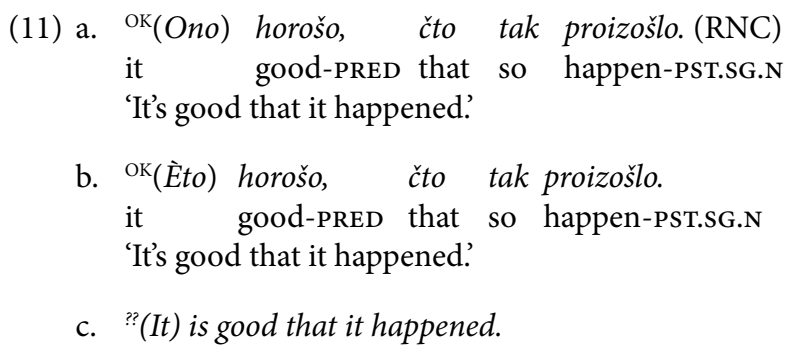

\subsubsection{Contrastiveness}

Ono can be neither focused nor contrasted, as is typical of an expletive (Greco et al. 2017: 70). In (12), èto cannot be substituted with ono, since it is contrasted by means of the particles vot and $i$.

(12) - Mne ne bol'no, babuška, govorju ja. -Vot

I-DAT not hurt-PRED grandmother say-PRS.1.SG I PTCL

èto $i$ ploho, čto ne bol'no. (RNC)

it PTCL bad-PRED that not hurt-PRED

'- It does not hurt me, grandmother, I say. - This is what is bad, that it does not hurt you.

Etto, as evidenced by (12), can be contrasted, but according to the data in RNC, in this case it can only refer to a prementioned state of affairs (the state of affairs 'it doesn't hurt you' in (12)). This suggests that it is the referential èto that can be contrasted and not the expletive one.

${ }^{7}$ An anonymous SPL reviewer points out that neither èto nor ono are admissible in other types of impersonal constructions in Russian (those that do not involve a right-peripheral complement clause). By itself, this fact should not come as a surprise, since expletives do not form a homogeneous class and languages may restrict the use of a particular expletive by a specific syntactic context (see Biberauer and van der Wal 2012 for a typological overview). The question remains, however, as to why a demonstrative (èto) and a personal pronoun (ono) in Russian came to be used as extraposition expletives without developing other expletive functions. 


\subsection{6. Èto and ono: interim summary}

The main conclusion that emerges from the presented data seems to be the following. Eto and ono are expletives or expletive-like items of the same functional type: they are used in the subject position, they combine with impersonal predicates and they are linked to a right-peripheral embedded clause. They do not represent different types of expletives, as do, for example, the English expletives it and there (Svenonius 2002: 4).

The main differences between èto and ono can be generalized as follows.

- Ono referring to a right-peripheral complement clause can be used only as an expletive, while èto has both expletive and referential uses.

- Ono is stylistically marked and restricted in use, while èto is stylistically neutral.

However, these differences don't contradict the assumption that èto and ono are expletives of the same functional type.

The parameters symptomatic of the expletive status of èto and ono are summarized below (the value associated with expletiveness is italicized).

A. New vs. given postcedent (section 2.1.1)

B. Pronoun precedes vs. follows the clause (section 2.1.2)

C. Nominative vs. oblique case (section 2.1.3)

D. Type of the predicate (impersonal vs. personal) (section 2.1.4)

E. Contrastiveness/focusability (yes vs. no) (section 2.1.5)

According to the parameter A, both ono and the expletive èto can, though must not, relate cataphorically to new information, while the referential èto can only refer to given information. According to the parameter B, both expletives can only precede the embedded clause, while the referential èto can follow it. According to the parameter $\mathrm{C}$, neither expletive can be marked for an oblique case. According to the parameter D, both expletives only co-occur with impersonal predicates (or predicates that can be used impersonally). According to the parameter E, neither expletive can be contrasted.

As, contrary to ono, èto can be both expletive and referential, the above parameters can serve to distinguish between two types of èto. Namely, èto is guaranteed to be an expletive if it is expletive according to all five parameters from A to E. When the postcedent of èto is given (the "referential value" of parameter A), the status of èto is unclear without further investigation. Finally, if èto displays at least one of the referential values from B to E, this is a sure symptom that èto is referential. ${ }^{8}$

\footnotetext{
${ }^{8}$ As is clear from this definition of the expletive èto, different parameters interact with each other when determining the status of èto (referential vs. expletive). See Pekelis (2018) for a detailed discussion.
} 


\subsection{The empirical data: $t a k$}

According to the parameters from $\mathrm{B}$ to $\mathrm{E}$, introduced in the previous section, tak can only be used as a referential pronoun. Indeed, tak can both precede the embedded clause (13a) and follow it (13b), and in neither case does it display features associated with expletiveness (parameter B).
(13) a. Mnogie tak dumajut, čto Kostjakov
many.people so think-Prs.3.PL that Kostjakov
ot Boga otkupaetsja. (RNC)
from God pay.off-PRs.3.sG
'Many people think (lit.: so) that Kostjakov pays God off.'
b. Čto Kostjakov ot Boga otkupaetsja, tak
that Kostjakov from God pay.off-PRs.3.sG so
mnogie dumajut.
many.people think-PRS.3.PL
'That Kostjakov pays God off, so many people think.'

Genetically, tak is an adverbial proform meaning 'so'. Consequently, tak is not marked for case, so the parameter $\mathrm{C}$ is not relevant for it. Furthermore, tak doesn't tend to combine with impersonal predicates, and in particular, it doesn't combine with predicatives (parameter D). Instead, tak is compatible with personal predicates such as dumat' 'think' and skazat' 'say', as shown in (13) and (14) respectively.
(14) Ja tak skažu, čto po mentalitetu ja russkij čelovek. (RNC)
I so say-FUT.1.SG that by mentality I Russian man
'I will say (lit.: so) that I'm a Russian by the mentality'.

Finally, tak can be contrasted (parameter E). In (15), tak is in the scope of the focus particle daže ('even').

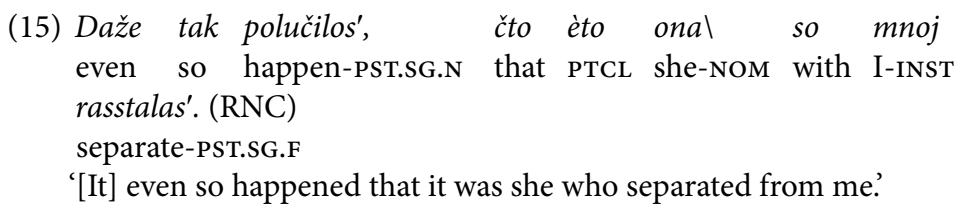

However, example (15) is contradictive. It shows that tak, being contrasted, can at the same time cataphorically refer to new information, which is a symptom of an expletive, according to the parameter A. Indeed, example (15) is naturally pronounced with the focus accent within the complement clause, and its broader context in RNC suggests as well that the piece of information it was she who separated from me' is assumed to be new by the speaker. A solution to this contradiction is suggested in section 3 . 


\section{Why is tak not an expletive?}

As shown above, four of five parameters characterize tak as a referential pronoun, and this is, I suggest, the correct analysis for tak. The fact that tak behaves differently from other referential pronouns (cf. parameter A) is presumably due to the status of an adverbial that tak has. This status, as I show below, is also linked to the fact that tak is not an expletive.

Indeed, even in case tak refers to a complement proposition, it doesn't assume the role of a complement, but remains an adverbial. One of the arguments in favor of this analysis is that tak can combine with èto or ono within the same clause and refer to one and the same sentential complement. This is the case in (16). Both tak and èto refer here to the sentential complement of the verb byvat' 'happen from time to time. Note that the antecedent in (16) is not a clause embedded under the matrix predicate (as was the case in all examples considered hitherto), but an independent sentence. Consequently, both proforms in (16) from RNC can a priori be assumed to take up the predicate's theta-role and, hence, to be referential.

(16) $V$ drugih slučajah [revnost' javljaetsja tol'ko

in other case-PL jealousy-NOM be-PRs.3.SG only

simptomom osnovnoj bolezni $]_{\mathrm{i}}, \quad$ tak $_{\mathrm{i}}$ èto $_{\mathbf{i}}$

symptom-INST underlying-GEN disease-GEN so it-NOM

byvaet pri isterii, paranoje,

happen.sometimes-PRS.3.SG with hysteria paranoia

progressivnom paraliče $i$ proč.

progressive paralysis and so.on

'In other cases, jealousy is only a symptom of the underlying disease, as (lit.: so it) sometimes happens with hysteria, paranoia, progressive paralysis, and so on.'

If, however, both èto and tak were referential complement proforms in (16), this would violate the general assumption that each semantic role is assigned to one and only one argument (Dowty 1991, a.o.). Now, it is hardly possible that tak is an adverbial in cases like (16), but a complement when referring to the right-peripheral complement clause. Its relation to the matrix predicate seems to be identical in these two cases.

Importantly, èto and ono, being both truly complement proforms, cannot combine with each other. This is evidenced by example (17), which is ungrammatical:

(17) ${ }^{*}{ }^{\mathrm{E} t o_{\mathrm{i}}}$ ono $\mathrm{i}_{\mathrm{i}}$ byvaet pri isterii, it-NOM it happen-PRs.3.SG with hysteria paranoje, progressivnom paraliče $i$ proč. paranoia progressive paralysis and so.on Intended meaning: 'This happens with hysteria, paranoia, progressive paralysis, and so on.' 
How can the adverbial status of tak be linked to its referential status? If it is a complement proform that refers to a right-peripheral embedded clause, as èto in (18a), its meaning adds nothing new to the meaning of the sentence, since the argument proposition is provided by the clause. This creates the conditions for the proform to be semantically empty. However, if it is an adverbial proform, as tak in (18b), the adverbial meaning it provides is expressed by no other item in the sentence, since the clause itself is a complement and not an adverbial. Hence, no similar conditions for semantic emptiness arise. ${ }^{9}$ Note that this idea, namely, that semantic factors might be at play in determining the expletiveness of a pronoun, is congruent with the fact that Russian has little, if any, syntactic need for an expletive.
(18) a. Eto byvaet, čto ženščiny
it-NOM happen.sometimes-PRS.3.SG that woman-NOM.PL
spokojnee mužčin. (RNC)
calmer man-GEN.PL
'It happens that women are calmer than men.'
b. Tak byvaet, čto ženščiny spokojnee
so happen.sometimes-PRS.3.SG that woman-NOM.PL calmer mužčin.
man-GEN.PL
'It (lit.: so) happens sometimes that women are calmer than men.'

The linkage between the adverbial status of tak and its capacity to cataphorically refer to new information seems to be essentially the same: tak can refer to new information because it has a meaning component that is not expressed by any other item in the sentence.

It is well-known that for referential pronouns, intrasentential cataphora is generally restricted to contexts where it appears from the left-peripheral subordinate clause, as in example (19) from Cann and McPherson (1999) (see also Quirk et al. 1985: 351; Trnavac and Taboada 2016). Here, a pitch accent (indicated by uppercase) on the NP Fred serves to signal that this NP has not yet been mentioned. Hence, this is the case of true cataphora.

(19) If she meets him, $_{\mathrm{p}}$ Mary ${ }_{\mathrm{i}}$ will give $F R E D_{\mathrm{j}}$ a book.

As for the right-peripheral embedded clause, it cannot be usually referred to as a matter of true cataphora, so the referential it, es and èto mainly refer to a prementioned state of affairs. Thus, in example (20) from Bolinger (1977: 68) the referential it in the object position is permissible, since the verb swallow is

\footnotetext{
${ }^{9}$ This does not mean, of course, that a pronoun that is an adverb synchronically or diachronically cannot be an expletive. The English expletive there would be a possible counterexample to such a generalization.
} 
factive, while it cannot be used in example (21), which features the verb guess (Bolinger 1977: 70).

(20) He can't swallow it that you dislike him.

(21) I guess $\left({ }^{*}\right.$ it) that you will win.

Crucially, it can be assumed that the ban on true cataphora holds only in case the pronoun and the postcedent are referentially identical, namely, denote one and the same referent. Only in this case the resulting relation is a true coreference. Note that expletives or expletive-like items, being semantically impoverished, do not meet this condition on true coreference and, predictably, are capable to refer cataphorically to a right-peripheral embedded clause that expresses new information.

Now, since tak is an adverbial and the corresponding right-peripheral clause is a complement, for them (just like for expletives) no referential identity emerges. Consequently, tak can cataphorically refer to new information without violating the ban on true cataphora.

\section{The function of èto and ono}

As mentioned in section 2.1.4, both èto and ono are usually optional as expletives. This means that they do not serve to fill the subject position, namely, to fulfill the syntactic function associated with expletives. The question that arises is what function èto and ono have and I suggest here that both èto and ono convey a discourse-related meaning. They signal to the addressee that the embedded proposition they refer to is, at least partly, given, i.e. mentioned in the pre-text.

A comment is due concerning the word "partly" above. I have assumed so far that the expletive èto and ono differ from the referential èto in that they can relate to new information (section 2.1.1). However, in the light of examples like (22) below, it rather seems that the proposition èto and ono refer to though it may, indeed, be partly new - must, however, be also partly given.

In (22), the embedded clause referred to by èto is a speaker's interpretation concerning the relations between the commander and the sailors. This interpretation is by itself new. Not surprisingly, the focal (falling) accent must be realized within the embedded clause. However, this interpretation is prompted by what was narrated by the addressee immediately before. In this respect, the embedded proposition can be said to be given. For this strictly pragmatic reason, the presence of èto in (22) is preferred with respect to its absence. If èto were absent, the embedded proposition would be perceived as completely new, i.e. not prompted by the pre-text, which is not the case here. 
(22) Ja rasskazal emu, kak matrosy rugajut

I-NOM tell-PST.SG.M he-DAT how sailor-NOM scold-PRS.3.PL

svoego komandujuščego. Vasiliev, vyslušav menja,

their-ACC commander-ACC Vasiliev-NOM listen-CNV I-ACC

zagovoril vozbuždenno. - ? (Èto) ploho, čto on ni

speak-PST.SG.M excitedly It bad-PRED that he-NOM not

$u$ kogo ne sumel zavoevat' $k$ sebe

with anyone not manage-PST.SG.M win-INF to himself

doverija $i$ sredi oficerov ne pol'zuetsja avtoritetom $\backslash$.(RNC)

confidence and among officer not enjoy-PRS.3.sG credibility

'I told him how the sailors scolded their commander. After he had listened to me, Vasiliev spoke excitedly: - It's bad that he failed to win anyone's confidence and that he doesn't enjoy credibility among the officers.'

More generally, the presence of èto or ono can be expected to be obligatory in case all five expletive features from A to E, including the (partial) newness of the postcedent (see section 2.1.6), are at play. If, however, the embedded proposition is completely given, as, for instance, in (11), the use of ono or èto (the one which is expletive according to the parameters from B to E) is optional since in this case, the signal that ono and expletive èto are assumed to transmit is clear enough from the embedded proposition itself. But even then, the presence of ono or èto seems to emphasize the givenness of the proposition they relate to. In particular, this seems to be a very subtle difference between (11a) with and without ono and between (11b) with and without èto.

Accordingly, both the expletive èto and ono can be expected to be inappropriate in case the embedded proposition is completely new. This prediction is borne out. Firstly, neither èto nor ono can be used if the embedded clause is prompted by a wh-question, which signals that the embedded proposition is completely unknown to the addressee. In example (23), the proposition Anya uezžaet 'Anya leaves' is unknown since it provides the answer to the wh-word in the preceding question. Neither èto nor ono is admissible here.

(23) Vsjo horošo, krome odnogo.

everything fine-PRED except one.thing

'Everything is fine, except for one thing.'

$\begin{array}{cllllll}-A & \text { čto ploho? } & - & \left({ }^{*} \dot{E} t o /{ }^{*} \text { Ono }\right) & \text { ploho, } & \text { čto Anya uezžaet. } \\ \text { and what bad-PRED } & \text { it it } & \text { bad-PRED that Anya leave-PRs.3.sG }\end{array}$ 'And what is not fine? It is bad that Anya is leaving.'

Secondly, the same effect manifests itself when the matrix predicate is modified by the adverb osobenno 'particularly'. When osobenno and the predicate precede the embedded clause, being in the topic position, the clause itself introduces a piece of information that is not prompted by the pre-text, hence, completely new. This trait of osobenno is evidenced by the prosodic constraints osobenno imposes on the embedded clause. In the presence of osobenno (24a), 
the embedded clause cannot be prosodically marked as a tail; it must obligatorily contain the focal (falling) accent. On the contrary, in case osobenno is absent, the embedded clause can get the tail intonation (24b).

$\begin{array}{lllll}\text { (24) a. Osobenno } & \text { obidno/, } & \text { čto } & \text { menja } & \text { obmanuli } . \\ \text { particularly } & \text { offensive-PRED that } & \text { I-ACC } & \text { deceive-PST.PL } \\ & \text { 'It is particularly offensive that I was deceived.' (RNC) } & \end{array}$

b. Obidnol, čto menja obmanuli.

offensive-PRED that I-ACC deceive-PST.PL

'It is offensive that I was deceived.'

As can be expected, neither èto nor ono can combine with osobenno. Thus, example (25a), with osobenno, is infelicitous with both èto and ono (25b), while example (25c), in which osobenno is omitted, is well-formed with either èto or ono:

(25) a. Osobenno ploho, čto ne hočetsja particularly bad-PRED that not want-PRS.3.SG

pisat'. (RNC)

write-INF

'It is particularly bad that [I] do not want to write.'

b. ('Èto/?Ono) Osobenno ploho, čto ne hočetsja pisat'.

c. ${ }^{\mathrm{OK}}$ Èto / ${ }^{\mathrm{OK}}$ Ono ploho, čto ne hočetsja pisat'.

Note that the pragmatic interpretation proposed for èto and ono suggests that they are not completely devoid of pronominal semantics, since they transmit a piece of information concerning the embedded proposition. However, this is far from having the fully-fledged pronominal semantics associated with the referential èto, which is characterized by the referential identity between the pronoun and its postcedent (according to what was suggested in section 3 ).

Importantly, both being discourse-oriented and to some extent contentful are not peculiar to Russian expletives alone. The English weather it, for instance, has been claimed to have some contentful features, too (Bolinger 1977 a.o.) and expletives with discourse-related functions have been reported for Dominican Spanish and Vietnamese (Greco et al. 2017).

\section{Summarizing the criteria for expletiveness}

In section 2.1.6, five parameters have been suggested, which have served to differentiate the expletive èto and ono from the referential tak. To what extent can these parameters be considered to be the general criteria for expletiveness in the construction with a right-peripheral embedded clause?

As alluded above, the majority of parameters, if not all of them, are also relevant, in one way or another, for the English it and the German es. Since 
Russian differs significantly from English and German with respect to subject omission, this suggests that these parameters are far from being language-specific, although, naturally, this assumption needs further investigation.

However, the parameters under discussion turn out to be revealing primarily when a pronoun behaves uniformly according to all five of them. This is exactly the case of èto and ono. Otherwise, as with all the syntactic diagnostics, individual parameter values can be due to the properties of the pronoun that are not linked to its expletive vs. referential status. This is the case of tak, which can refer to new information (parameter $\mathrm{A}$ ) being a referential pronoun.

\section{Conclusions}

The following conclusions emerge from the presented data.

- Russian is among languages that both allow null subjects and make use of expletives or expletive-like elements.

- In the construction with a right-peripheral complement clause, Russian features two expletive pronouns of the same functional type, which differ mainly stylistically. They are both optional devices and convey a discourse-related meaning.

- A careful analysis is needed to uncover whether or not a pronoun has a referential meaning, since the elements that at first sight seem functionally similar may turn out to differ significantly. This is the case of èto and ono, on the one hand, and tak, on the other. What seems to be responsible for the referentiality of tak is the a priori absence of referential identity between tak and its postcedent, which, in turn, is due to the adverbiality of tak.

- The traits of the Russian expletives èto and ono may be considered to be general, non-language-specific criteria for expletiveness, since they are also relevant for English and German, languages that are commonly assumed to differ from Russian with respect to expletives.

\section{References}

Biberauer Theresa, van der Wal Jenneke (2012). Why languages don't like expletives. Paper presented at Syntax of the World's Languages V Conference, Dubrovnik, October 2012. [URL: https://recos-dtal.mml.cam.ac.uk/Publications/publicationsfolder/jw-handout-swl-5-expletives; accessed December 4, 2018].

Birner Betty, Ward Gregory (2004). Information structure and non-canonical syntax. In The Handbook of Pragmatics, Laurence R. Horn and Gregory Ward (eds.), 153174. Oxford: Blackwell Publishing.

Bolinger Dwight (1977). Meaning and Form. English Language Series, 11. London: Longman.

Bryzgunova E.A. (1980). Intonacija [Intonation]. In Russkaja grammatika [Russian grammar], Natalja Ju. Švedova, Nina D. Arutjynova, Aleksander V. Bondarko, 
Valerij V. Ivanov, Vladimir V. Lopatin, Igor S. Uluhanov, and Fedot P. Filin (eds.), vol. I, 96-120. Moscow: Nauka.

Cann Ronnie, McPherson Catriona (1999). Interclausal cataphora in English. Ms., PPLS University of Edinburgh and University of Leeds. [URL: http://www.ling. ed.ac.uk/ ronnie/cat99-pretty.doc; accessed October 5, 2018].

Dowty David (1991). Thematic proto-roles and argument selection. Language 67(3), 547-619. DOI: 10.2307/415037

Frey Werner, Meinunger André, Schwabe Kerstin (eds.) (2016). Inner-sentential Propositional Proforms: Syntactic Properties and Interpretative Effects [Linguistics Today]. Amsterdam/ Philadelphia: John Benjamins.

Greco Ciro, Haegeman Liliane, Phan Trang (2017). Expletives and speaker-related meaning. In Order and structure in syntax II: subjecthood and argument structure, Michelle Sheehan and Laura R. Bailey (eds.), 69-93. Berlin: Language Science Press.

Letučij Alexander (2011). Bezličnost' [Impersonality]. In Materialy dlja proekta korpusnogo opisanija russkoj grammatiki [Towards a corpus description of Russian grammar]. Ms., Moscow. [URL: http://rusgram.ru; accessed April 3, 2019].

Malchukov Andrej, Siewerska Anna (2011). Introduction. In Impersonal Constructions, Andrej Malchukov, and Anna Siewerska (eds.), 1-15. Amsterdam-Philadelphia: John Benjamin.

Pekelis Olga E. (2018). Expletives, referential pronouns and pro-drop: The Russian extraposition pronoun èto in light of the English it and the German es. Lingua 203, 66-101.

Quirk Randolph, Greenbaum Sidney, Leech Geoffrey, Svartvik Jan (1985). A Comprehensive Grammar of the English Language. London: Longman.

Russian National Corpus. [URL: www.ruscorpora.ru; last accessed December 5, 2018]. Roberts Ian, Holmberg Anders (2010). Introduction: parameters in minimalist theory. In Parametric Variation: Null Subjects in Minimalist Theory, Theresa Biberauer, Anders Holmberg, Ian Roberts, and Michelle Sheehan (eds.), 1-57. Cambridge: Cambridge University Press.

Schwabe Kerstin, Frey Werner, Meinunger André (2016). Sentential proforms: an overview. In Frey, Meinunger, Schwabe (eds.), 1-22.

Sudhoff Stefan (2016). Correlates of object clauses in German and Dutch. In Frey, Meinunger, Schwabe (eds.), 23-48.

Svenonius Peter (2002). Introduction. In Subjects, Expletives, and the EPP, Peter Svenonius (ed.), 3-27. Oxford: Oxford University Press.

Trnavac Radoslava, Taboada Maite (2016). Cataphora, backgrounding and accessibility in discourse. Journal of Pragmatics 93, 68-84.

Vikner Sten (1995). Verb Movement and Expletive Subjects in the Germanic Languages. Oxford: Oxford University Press.

Olga E. Pekelis

Russian State University for the Humanities

Miusskaya sq. 6

Moscow 125993

Russia

opekelis(at)gmail.com 
